\title{
Customer Service Quality Perception of Internet
}

\section{Banking}

\author{
M. Taimoor Hassan \\ Department of Management Sciences, The Islamia University Bahawalpur, Pakistan
}

Aqeel Mukhtar, Rana Kaleem Ullah, Huzaifah Shafique and Shafi Ur Rehmna

Department of Management Sciences, The Islamia University Bahawalpur, Pakistan

\begin{abstract}
Abia Anwar
Language Instructor, Pakistan Reading Association, Pakistan
\end{abstract}

Accepted: March 5, 2012 Published: April 04, 2012

Doi:10.5296/ijld.v2i2.1591ＵRL: http://dx.doi.org/10.5296/ijld.v2i2.1591

\begin{abstract}
Purpose: The purpose of this study is to find out the determinants that mainly affect the customer service quality perception of internet banking amongst genders and different age groups.

Design/methodology/approach: Sample of 120 internet banking customers was used to gather data, which was further utilized to find out how 8 major determinants affect the customer service quality perception of internet banking.

Findings: The research found that Web design, security, trust, product diversification, credibility, collaboration, access and communication strongly affect the customer perception about the quality of internet banking service.

Research limitations/implication: The data was gathered from the banks in Bahawalpur which limited the scope of this study particularly to this region so future research can be done to gathered data from all over the Pakistan so that the cross cultural factors could be identified clearly.
\end{abstract}

Keywords: $\quad$ Service Quality Perception, Dimensions of Internet Banking, Bahawalpur. 


\section{Introduction}

2012, Vol. 2, No. 2

Providing service to the customers through internet is regarded as internet banking. Web Based services provide the customers with the bundle of easily accessible and manageable services such as reduction in cost of transactions and managing one's account at hand. (Scullion and Nicholas, 2001; Unsal and Movassagi, 2001; Zeithaml,2002). It also enables the customers to manage their accounts with few clicks, making their services cheap and convenient. The concept of " e-banking” emerged along with the growth of internet. Banking industry was urged to develop the web based services due to low cost and to attract customers and increase the efficacy within the banking sector (Rust and Kannan, 2003). To compete in the global world of internet banking it is essential to provide the customer with best possible services (Mefford, 1993). In doing so the difference between the customers' expectations and the provision of the services by the banks should be determined to evaluate the quality of the services. (Parasurman et al; 1985, 1988)

Almost every bank today provides the service of internet banking. Hence it is important for the banks to know the determinants that influence the customer adaption of internet banking. Giving the services through internet is not enough but providing the quality service is the main thing. There are many factors that make the service good enough for the customers to be adopted. Web design, security, trust, product diversification, credibility, collaboration, access and communication are some of the factors that make the perception of customer about the quality of internet banking service.

\section{Literature review}

Trust:

The nature of many businesses is determined by trust and trust also works in speeding up many transactional associations (Gefenet al. 2003). Supposed reliability is trust's dimension, it means that up to what extent one partner thinks that the other one is capable of effectively performing a job (Ganesan, 1994).

Online transaction trust of the customer has decreased because, while having transactions both of the parties are not having face-to-face communication (Cho et al. 2007). Trust is the vital issue regarding the use of e-banking, for both of the parties (bank \& customers) are not having face-to-face communication as well as there is also uncertainty in the user's mind about the security of online transaction. If the customer's trust is low on online system than opportunities that can be explored from the internet based banking could be restricted (Rotchanakitumnuai and Speece, 2003). Reasons for not fully entrusting the online banking are numbered that are, system's security, lack of trust on provider of the service, and uncertainties about the dependability of internet based services. (Lee and Turban, 2001; Min and Galle, 1999; Rotchanakitumnuai and Speece, 2003).

When talking about the word trust it does not mean the trust on the service provider but the system through which it is being provided. (Sydow, 1998). Web as a medium for transactions is also needed to be trusted along with the trust of online consumers on sellers (McKnight and 
Chervany, 2002). Therefore to built trust in online businesses, it is suggested that anyone designing online system should be well aware of what he or she is doing and the basic goal of the work should always be kept in mind to get the positive result. (Rea, 2001).

Web Design/Features factor:

For the deliverance of banking products, online banking is the economical channel (Sathye, 1999; Robinson, 2000; Giglio, 2002) which reduces the cost of man power. (Karjaluoto, Koivumaki and Salo, 2003). On the other hand it is not that all the financial businesses using internet banking are flourishing with the use of this technology (Hernández-Ortega, Jiménez-Martínez, and Hoyos, 2007). Failures in online banking are often associated with the poor design of the website (Hernández-Ortega et al. 2007).

A website which is easily navigable makes it easy for the users to get their desired information and quickly finish their operations (Hernández-Ortega et al., 2007). So to be successful on internet based businesses, fine website design is also required along with the satisfactory products (Hernández-Ortega et al., 2007). Construction of easily navigable website should also be included in the strategies of internet banking (Serrano-Cinca, Fuertes-Callén, and Gutierrez-Nieto, 2007). User of internet banking anticipate that the online system will be beneficial than traditional banking and in other ways also alike, would be speedy and would save time and would also be beneficial economically (Karjaluoto, 2002 b; Goi, 2007). User responsive website must also be there for getting all these advantages (Hernández-Ortega et al., 2007). So the most important way of transmission for banks is the design of website (Liu and Arnett, 2000; Zhang and von Dran, 2001; Liao, Huang and Chen, 2007). Operability and usability that a website should offer to its consumers is known as navigability (Hernández-Ortega et al., 2007). Search options provided by the website for users to find what they are looking for is navigability characteristic (Huizingh, 2000). Satisfaction of the users would be greater when there would be greater navigability and user requires few clicks to get his desired object (Hernández-Ortega et al., 2007). The chances of getting more loyal customers would increase when the navigability is easy (Hernández-Ortega et al., 2007). It is possible that a user may not be able to finalize his/her transaction due to poorly designed website furthermore he/she may not visit that website again for financial transactions(Hernández-Ortega et al., 2007).

Ease to Uses:

It means that up to what extent person believes that the use of specific system would improve his/her performance of work (Davis, 1989; Davis et al., 1989; and Mathieson, 1991).Researches over past decades shows that perception is derived directly or indirectly about the usefulness of a service from its ease of use (Agarwal and Prasad, 1999; Davis et al. , 1989; Hu et al. , 1999; Jackson et al. , 1997; Venkatesh, 1999, 2000; Venkatesh and Davis, 1996, 2000; Venkatesh and Morris, 2000). E-banking is also very much enjoyable because using computers is very interesting and enjoyable activity (Davis, 1989). Another use of this system that with the enjoyment of using computer people are also motivated and committed to their work, in this way they gain both enjoyment and motivational factor (Pikkarainen , 2004).

Security: 
Generally security concept refers to the capability of defending against possible fears. But in internet banking it means the capability of the online firm to protect the information and transaction of the consumer from being stolen. Apparent controls of the security shows that up to what extent the website for businesses is able to protect from possible threats and is thought to be secure (Hua, 2009).

In many of the studies conducted it is seemed that security and privacy is very essential in online banking (Sathye, 1999; Hamlet and Strube, 2000; Tan and Teo, 2000; Polatoglu and Ekin, 2001; Black et al., 2002; Giglio, 2002; Howcroft et al., 2002). It is also noticed that people are least aware of the risks in online banking even though they are aware of the risks (Roboff and Charles, 1998). Moreover it is also noticed that consumer believes that the bank they are associated with will is very much concerned about privacy matters and it is determinant to protect them. It is also argued that consumer is very much confident about their bank but they have less confidence in technology (Howcroft et al., 2002). In many of the transaction matters mostly consumers were concerned about lack of security in transaction from credit cards, few alternators' for payments and service providers can not be identified fully (Farm and Grady, 1995). Similarly most significant barrier that stops the online browsers from becoming buyers is fear of doing online transaction (Then and Delong, 1999). Here security means that consumer has perceived that the online firms are not capable of preventing their information of transaction form being stolen at any stage (Belanger et al., 2002; Salisbury et al., 2001) and it is the cancers that has great impact on someone's buying decision (Yang and Jun, 2002). Therefore rate of online buying of the product in strongly related to the security steps taken by the website (Miyazaki and Fernandez, 2001)

\section{Product Diversifications:}

Those Bank customers, who use internet, will prefer internet banking because it is more convenient than the traditional banking and banks introduce their products when numerous customers prefer to online transaction. Through internet banks customers wants to pay their utility bills, monthly statement and for online transfer or receive their money. There is a possibility for companies with line of product can attract numerous customers (Yang's, Jun.M and Peterson, 2004). Electronic banking covers a broad area of technological advancement which has been established and going toward further achievements. In these technologies some are called front end products which customer uses just like ATM cards and online banking and some other technologies are called back end. These technologies used big institution and service organizations for the purpose of transactions for example online check transaction. Research is conducted about Consumer behavior and use of online banking which determined that consumer behavior about e banking is definite at initial stage through many factors just as economic power, literacy rate and attitude about banks advancement. If customer know about computer and new advancement of the world can easily adopt online banking product and service (Labored, 2005).Internet banking introduces many technologies for the betterment of people such as ATM, mobile banking, online transaction and recently banks introduce easy paisa service. Automated teller machine is the electronic machine which enables the customer to draw money or other online transaction by inserting a card in Internet banks. Mobile banking is another improvement of internet banking. Internet banking introduces a mobile banking. Credibility: 
Credibility is the confidence that one person tries to find from another which he desires from him apart from what is the feared (Deutsch, 1973). For credibility it is necessary for bank to ensure its good reputation and must give confidence to customer about its services. There are many fears in the mind of customer but if the credibility of that particular bank is at high level than the customer will be assured that his transactions with that bank are safe and there is not much to worry about. If the credibility of bank is below par than the chances of risk will be certainly increased enabling customer not to trust easily. The two main elements of credibility are security and privacy. if the data of customer is private and secure than there will be less chances of any mishap and consistency is the quality of service that banks keeps on providing at a level which does not decrease (Handing ,2007). Security in e banking means that the personal information and the transactions of customer are in safe hands (Egwali, 2008). There are also many disadvantages of e banking and the biggest disadvantage is definitely the insecurity about it in the mind of customer and because of it the e banking is under rated but the new techniques applied in e banking are definitely gaining the trust of customer and people are shifting towards it. A factor which involve in the hurdles of progress and development of e commerce and also in adoption of e banking is a fear with minimum security (Ezeoha, 2005).

\section{Collaboration:}

Banks needs a valuable solution of safe collaboration with groups in both sides internal and external. The current methods for collaboration are internet and meetings. Banks introduced a new idea for the collaboration of customer in-between 1995-96. Banks were limited in nice situation which was normally used to send its vision to customer (Wolf \& Zadrozny, 1998). Collaboration is the tool which helps the customer to link with their bank. With those organizations which have large number of employees where may be a large number of internet bank users these techniques make the employees to work each other.

Access:

Through the bank web sites customer can check his account balances and current bank statement. A system through which customer starts his online transactions just like transferring his money between the accounts; provide extra benefits to the customer. These advance web sites ensure the customers to check his credit card balance, pay their bills and he can apply for loans or review them. The aim of providing a well expanding online service from the financial institution is that to be ensured in the market as a leader (Hickman, 1999).Although internet banking services are improved through internet and also in the access of consumers but consumers also need to go on ATM or bank branch. In banking customer can deposit their money by mail, by ATM or by visiting the branch of bank (Fysh, 1990).

Through these characteristics there are some issues of e-banking which is required to address by e banking for example, more than one transaction in ATM is not allowed and more fee charge as compare with the transaction of cheques.

Apart from this ATM is considered a most convincing way of e-banking. To reduce this problem-banks are trying to close a customer on limited number of ATM transactions within the month. Electronic cash will be used as our solution in future but it could not be received well in the society (Nath, Ravi.Schrick, Paul.Parzinger, Monica, 2001). E-mail is another way to access e-banking. It provides a link to communicate with the bank. It is also provides the facility of feedback of your question which you have asked to bank related with your account. 
E-mail is not used to start transactions on your account. Internet banking has helped a customer to access the bank in all the time by introducing a facility of mobile banking. As we know that the usage of mobile in south Asia, China and Korea has increased at large scale. Banks which provide access of mobile can provide following services: Bank sends Alerts about your account. You can recharge a balance and can pay utility bills. Customer receives wishes and loyalty base messages from a bank.

Communication:

Communication is the technology which is a link between hardware and software devices and flow of data from one place to another place (Loudon and Loudon; 2001). There are some services of banks which have groomed by using informational and communication technology. It has provided an automatic customer service machine which help the wiling (expected) customers to fill their account opening forms online. It also informs the customers about the validity of their accounts and provides instructions about their credit cards and cheque books (Agboola.A, 2001). Banks communicate their customers in different ways in sometimes they send messages on their cell phones and in the bank they place a person who provide information to customer. 


\section{Theoretical Framework:}

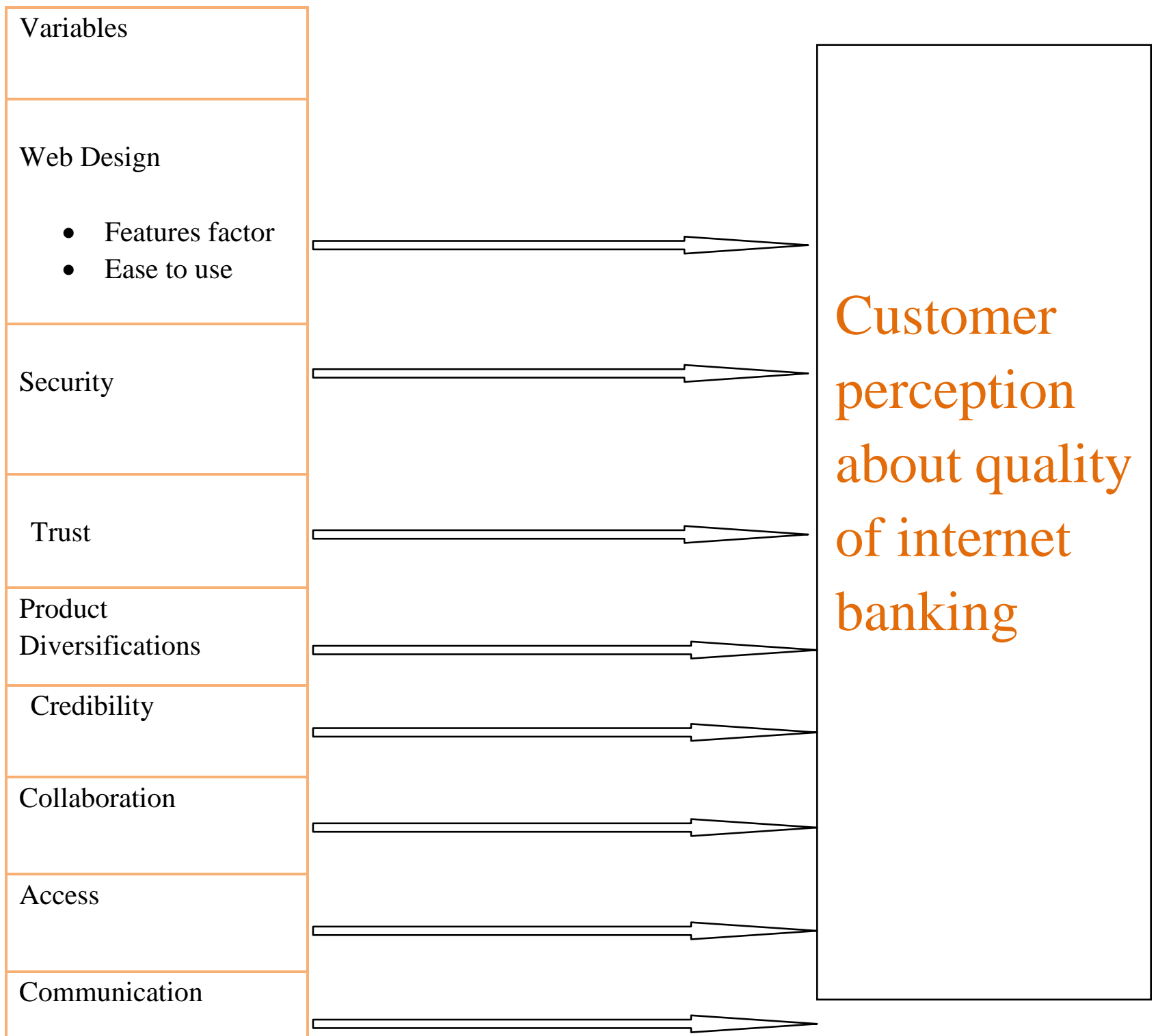

Independent

variables

Dependent variable

\section{Hypothesis}

We formulate eight hypothesis to test the relationship of independent and dependent variable by discussing the theoretical framework. The hypothesis is as under.

$\mathrm{H} 1$ : There is a relationship between web design and service quality perception of e- banking $\mathrm{H} 2$ : There is a relationship between credibility of e-banking services and customer perception about quality service of internet banking. 
H3: Security of the services of e-banking has a significant relationship with customer service quality perception of internet banking.

H4: There is a significant relationship between collaboration and customer service quality perception of internet banking.

H5: There is a positive relationship between customer access of e-banking services and their perception about service quality of internet banking

H6: There is a relationship between product diversification of internet banking services and their perception about service quality of internet banking

H7: Trust on internet banking has a significant relationship with customer perception about service quality of internet banking.

$\mathrm{H8}$ : There is a relationship between communication and customer service quality perception of internet banking.

\section{Results:}

$69 \%$ of our target respondents were male and $31 \%$ were female, of which age of $36.6 \%$ males were lying between 20 and 30 and 34.2\% males were between the age of 20-40. 18.3\% and $10.3 \%$ of males and females were lying in the age group of 40-50 and 50-60 respectively.

\begin{tabular}{|l|l|l|l|}
\hline Variable & mean & S.D & Variance \\
\hline Web design & 1.81 & 0.92 & 0.85 \\
\hline Feature factor & 1.97 & 0.97 & 0.94 \\
\hline Ease to use & 1.95 & 0.99 & 0.99 \\
\hline Credibility & 2.04 & 1.1 & 1.2 \\
\hline Security & 1.95 & 0.99 & 0.97 \\
\hline Privacy & 2.04 & 0.97 & 0.95 \\
\hline Secure transactions & 1.9 & 0.88 & 0.78 \\
\hline Collaboration & 1.98 & 0.99 & 0.97 \\
\hline Access & 1.99 & 1.01 & 1.02 \\
\hline $\begin{array}{l}\text { Product } \\
\text { diversification }\end{array}$ & 2.11 & 0.98 & 0.95 \\
\hline Trust & 2.29 & 0.94 & 0.88 \\
\hline Trust deficit & 2.31 & 1.22 & 1.49 \\
\hline Communication & 1.93 & 0.81 & 0.65 \\
\hline $\begin{array}{l}\text { Customer } \\
\text { perception }\end{array}$ & 2.03 & 0.84 & 0.7 \\
\hline
\end{tabular}

According to the responses gathered from our target population, mean value of variables lies from 1.81-2.11. It means that our respondents agree that these determinants are essentials for providing quality service. Credibility, access and trust are strongly deviated from the mean and there is normal deviation in remaining determinants. 


\begin{tabular}{|l|l|l|l|}
\hline Variable & Chi-square & $\begin{array}{l}\text { level of } \\
\text { association }\end{array}$ & $\begin{array}{l}\text { Remarks } \\
\text { accept-H0/accepteH1 }\end{array}$ \\
\hline Web design & 9.92 & Highly significant & Accept H1 \\
\hline Feature factor & 6.08 & Highly significant & Accept H1 \\
\hline Ease to use & 23.61 & $\begin{array}{l}\text { Moderately } \\
\text { significant }\end{array}$ & Accept H1 \\
\hline Credibility & 11.99 & Highly significant & Accept H1 \\
\hline Security & 15.51 & Highly significant & Accept H1 \\
\hline Privacy & 7.74 & Highly significant & Accept H1 \\
\hline Secure transactions & 23.28 & Highly significant & Accept H1 \\
\hline Collaboration & 10.68 & Highly significant & Accept H1 \\
\hline Access & 15 & Highly significant & Accept H1 \\
\hline Product diversification & 6.65 & Highly significant & Accept H1 \\
\hline Trust & 20.21 & Highly significant & Accept H1 \\
\hline Lack of trust & 20.1 & Highly significant & Accept H1 \\
\hline Communication & 18.29 & Highly significant & Accept H1 \\
\hline
\end{tabular}

For testing the hypothesis $5 \%$ level of significance is used in all hypotheses.

For first factor web design calculated value of $\chi^{2}=9.92$.We obtained $\mathrm{P}$ value 0.87 with 16 degree of freedom. Since calculated value of chi square is greater than the $P$ value $=0.87$. Sub variable of web design feature factor and ease of use has value of $\chi^{2} 6.08$ and 23.61 and $\mathrm{P}$ values $0.99,0.09$ with degree of freedom 16 . Since both calculated values of chi squares are greater than the $\mathrm{p}$ values. So we reject $\mathrm{H} 0$ and accept $\mathrm{H} 1$ at $5 \%$ level of significance and we conclude that there is a positive relationship between web design and customer service quality perception of internet banking. .If the website will be easily navigable than the customers will be more motivated to use internet banking because the operations will be easily performed.

Calculated value of chi square for credibility is 11.985 .Its $\mathrm{p}$ values is 0.75 with 16 degree of freedom. Calculated value of chi square is greater than the $p$ value so we accept alternative hypothesis and we conclude that there is a relationship between credibility of e-banking services and customers' perception about quality service of internet banking if the services are credible then the customers will perceive the quality of internet banking good.

For variable security calculated value of $\chi^{2}=15.509$. Its $P$ value is 0.49 with 16 degree of freedom. Value of chi square is greater than the $\mathrm{p}$ value and sub variables privacy and secure transaction have also values of $\chi^{2}=7.739,23.28$ and $p$ values $0.956,0.106$. Since both sub variables have values of chi square greater than the $p$ values of both sub variables. So we conclude that Security of the services of e-banking has a positive relationship with service quality perception of e-banking. . The higher level of individual transaction security in e banking services is based on privacy, individual transaction, branchless locations, and the timely performance could lead towards customer in developing the perceptions of the customers towards e - banking services. 
From collaboration calculated value of chi-square is 10.68 . We calculate $P$ value 0.83 with 16 degree of freedom. Chi square value 10.68 is greater than the $\mathrm{p}$ value $=0.83$ so we accept $\mathrm{H} 4$ and we can conclude that there is a positive relationship between collaboration and customer service quality perception of internet banking.

From access we calculate value of $\chi^{2}=15.00$. P value is 0.53 with 16 degree of freedom. Since calculated value of chi square is greater from $p$ value so we accept statement of alternative hypothesis which state that there is positive relationship between customer access of internet banking services and their perception about service quality of internet banking. . Analysis of the data indicates that all the information regarding banking service should be easily access able.

We obtain value of chi square from variable product diversification is 6.65 and we use level of significance $5 \%$.Value of chi square of this variable is also greater than the $\mathrm{p}$ value $=0.98$. So we accept alternative hypothesis and we conclude that there is positive relationship between product diversification and customer service quality perception of internet banking. Diversified services provided would make the customer loyal.

Since from variable trust, calculated value of $\chi^{2}$ is 20.21 . P value is 0.21 with 16 degree of freedom. Its sub variable lack of trust has value of $\chi^{2}=20.09$ and $p$ value is 0.22 . Now chi square values of trust and lack of trust are greater than the $\mathrm{P}$ values. So we reject null hypothesis and accept alternative hypothesis. We conclude that Trust in e-banking has a positive relationship with customer perception about service quality of e-banking. Trusting the online system is basic necessity for the customer to perceive the online banking quality good. In communication value of $\chi^{2}=18.29$. We calculate $P$ value 0.31 with 16 degree of freedom 16 . $\mathrm{P}$ value $=0.31$ is smaller than the value of chi square so we accept this statement which state that there is positive relationship between customer communication and their perception about service quality of internet banking. . Healthy communication is the necessity for making any relationship trust worthy.

\section{Conclusion:}

This research was conducted to find out the effects of different dimensions on the service quality perception of internet banking. As internet banking is increasing rapidly so it is important for the banks to know the preferences of the customers, when using internet banking. 8 main determinants were taken and their affect on the acceptance of internet banking was measured.

Easily navigable website would be comforting for customers and they would prefer to use online services. Trustworthy and secured online system, if provided, would make the decision easy for the customer moving to internet banking. According to our research respondents, it is very important that their transactions and personal information must be fully secured. In case of any query there must not be communication gap and customer have access to the management and banking staff when needed. If banks works on these determinants that it would surely increase its customers using online banking.

All the respondents were from people within the city; therefore it is possible that the results are influenced by social factors and values of the people. This research would be very effective in 


\section{Macrothink

Bahawalpur as compared to other areas. It is also strongly recommended for further researchers to use diversified sampling techniques to gather data. 


\section{Reference:}

Agarwal, R., Prasad, J. (1999), "Are individual differences germane to the acceptance of new information technologies?", Decision Sciences Vol. 30 No.2, pp.361-91.

Agboola, A. A. (2001) "Impact of Electronic Banking on Customer Services in Lagos, Nigeria" in Ife Journal of Economics and Finance. Department of Economics, O.A.U, Ile-Ife, Nigeria, vol. 5, Nos. 1\&2

Belanger, F., Hiller, J. S. \& Smith, W. J. (2002) Trustworthiness in electronic commerce: the role of privacy, security, and site attributes. Journal of Strategic Information Systems, 11, 245-270.

Black, N.J., Lockett, A., Ennew, Ch., Winklhofer, H. and McKechnie, S. (2002), "Modelling consumer choice of distribution channels: an illustration from financial services", International Journal of Bank Marketing, Vol. 20 No. 4, pp. 161-73.

Cho, D.Y., Kwon, H.J. \& Lee, H.Y. (2007) Analysis of trust in internet and mobile commerce adoption. Proceedings of the 40th Hawaii International Conference on System Science, USA.

Davis, F.D. (1989), "Perceived usefulness, perceived ease of use, and user acceptance of information technology”, MIS Quarterly, Vol. 13 No. 3, pp. 319-40.

Davis, F.D., Bagozzi, R.P. and Warshaw, P.R. (1989), "User acceptance of computer technology: a comparison of two theoretical models", Management Science, Vol. 35 No. 8, pp. 982-1003.

Fram, E.H. \& Grady, D.B. (1995) Internet buyers: Will the Surfers become Buyers? Direct Marketing, 58, 6, 63-65

Ganesan, S. (1994), "Determinants of long-term orientation in buyer-seller relationships", Journal of Marketing, Vol. 58 No.2, pp.1-19.

Goi, C. L. (2007). A review of existing web site models for e-commerce. Journal of Internet banking and Commerce, April, 12(1).

Gefen, D., Karahanna, E., Straub, D.W. (2003), "Trust and TAM in online shopping: an integrated model", MIS Quarterly, Vol. 27 No.1, pp.51-90.

Giglio, V. (2002). Privacy in the World of cyberbanking: emerging legal issues and how you are protected. The Secured Lender, No. March/April, 48-60. 
Hamlet, C. and Strube, M. (2000), "Community banks go online", ABA Banking Journal's 2000 White Paper/Banking on the Internet, March, pp. 61-5.

Hernández-Ortega, B., Jiménez-Martínez, J., and Hoyos, M. J. M. D. (2007). An analysis of Web Navigability in Spanish Internet Banking. The Journal of Internet banking and Commerce, December 2007, Vol. 12, No. 3.

Hickman, Meredith. "Internet Banking: Transaction to Active Selling," Bank Systems \& Technology (36), 1999, p. 3-14.

Hu, P.J., Chau, P.Y.K., Sheng, O.R.L., Tam, K.Y. (1999), "Examining the technology acceptance model using physician acceptance of telemedicine technology", Journal of Management Information Systems, Vol. 16 No.2, pp.91-112.

Hua, G. (2009) An Experimental Investigation of Online Banking Adoption in China. Journal of Internet Banking and Commerce, 14, 1, 1-12.

Huizingh, E. K. R. E. (2000). The content design of web sites: an empirical study. Information and Management, 37, 123-134.

Howcroft, B., and Hamilton, R., and Hewer, P. (2002). Consumer attitude and the usage and adoption of home-banking in the United Kingdom. International Journal of Bank Marketing. Vol. 20 (3), pp. 111-121.

Jackson, C.M., Chow, S., Leitch, R.A. (1997), "Toward an understanding of the behavioral intention to use an information system", Decision Sciences, Vol. 28 No.2, pp.357-89.

Karjaluoto, H. (2002 b). Electronic banking in Finland: consumer beliefs, attitudes, intentions and behaviors. PhD dissertation, University of Jyvaskyla, Finland.

Karjaluoto, H., Koivumaki, T., and Salo, J. (2003). Individual differences in private banking: empirical evidence from Finland. Proceedings of the 36th Hawaii International Conference on System Sciences (HICSS), Big Island, Hawaii.

Laudon, D.P. and Laudon, J.P. (1991): Business Information System: A Problem Solving Approach, New York, HBJ, College Publishers.

Liao, S.S., Huang, H.M., and Chen, G.D. (2007). An activity-theoretical approach to investigate learners ${ }^{e e}$ factors toward e-learning systems. Computers in Human Behavior, 23(4), 1906-1920.

Lee MKO, Turban E (2001), “A Trust Model for Consumer Internet Shopping”, Int. J. Electronic Commerce, 6 (1): 75-91. 
Liu, C., and Arnett, K. P. (2000). Exploring the factor associated with web site success in the context of electronic commerce. Information and Management, 38, 23-33.

Mathieson, K. (1991), "Predicting user intentions: comparing the technology acceptance model with the theory of planned behavior", Information Systems Research, Vol. 2 No.3, pp.173-91.

Mefford, R.N. (1993), "Improving service quality learing from manufacturing",International Journal of Production Economics, Vol 30, pp. 399-413.

McKnight, D.H. \& Chervany, N.L. (2002) What Trust Means in E-commerce Customer Relationships: An Interdisciplinary Conceptual Typology. International Journal of Electronic Commerce, 6, 2, 35-59

Miyazaki, A.D. \& Fernandez, A. (2000) Internet Privacy and Security: An Examination of Online Retailer Disclosures. Journal of Public Policy \& Marketing, 19, 1, 54-61.

Parasurman, A., Zeithaml, V.A and Berry, L.L (1985), "A conceptual model of service quality and its implication for future research",International Journal of Marketing, Vol 49, pp. 40-50

Pikkarainen, T., Pikkarainen, K., Karijaluoto, H. and Pahnila, S. (2004), Customer acceptance of on-line banking: an extension of the technology acceptance model, Internet Research, 14(3), pp. 224-235

Polatoglu, V.N \& Ekin, S. (2001) An empirical investigation of the Turkish consumers' acceptance on Internet banking services. The International Journal of Bank Marketing, 19, 4/5, 156-166.

Rea, T. (2001) Engendering Trust in Electronic Environments: Roles for a Trusted Third Party In C. Castelfranchi \& Y.-H. Tan, (Eds.), Trust and Deception in Virtual Societies. 221-236. Netherlands: Kluwer Academic Publishers

Robinson, T. (2000). Internet banking: still not a perfect marriage. Informationweek.Com, April 17, 104-106.

Roboff, G. and Charles, C. (1998), "Privacy of financial information in cyberspace: banks addressing what consumers want", Journal of Retail Banking Services, Vol. XX No. 3, pp. 51-6.

Rotchanakitumnuai Siriluck and Speece Mark (2003), "Barriers to Internet Banking Adoption: A Qualitative Study Among Corporate Customers in Thailand”, Int. J. Bank Managt., 21 (6/7): 312-323. 
Rust, R.T. and Kannan, P.K. (2003), "E-service: a new paradigm for business in the electronic environment", Communications of the ACM, Vol. 46 No. 6, pp. 37-42.

Salisbury, W. D., Pearson, R. A., Pearson, A. W. \& Miller, D. W. (2001) Perceived security and World Wide Web purchase intention. Industrial Management \& Data Systems, 101, 3-4, 165-176.

Sathye, M. (1999). Adoption of Internet Banking by Australian consumers: an empirical investigation. The International Journal of Bank Marketing. 17(7), pp.324-334.

Scullion, M. and Nicholas, D. (2001), "The impact of the Web on the stockbroking industry: big bang 2", Aslib Proceedings, Vol. 53 No. 1, pp. 3-22

Serrano-Cinca, C., Fuertes-Callén, Y., and Gutierrez-Nieto, B. (2007). Online reporting by banks: a structural modeling approach. Online Information Review, 31(3), 310-332.

Sydow, J. (1998) Understanding the Constitution of Inter-organizational Trust In C. Lane \& R. Bachmann, (Eds.), Trust within and between Organizations: Conceptual Issues and Empirical Applications. 31-63. Oxford: Oxford University.

Tan, M. \& Teo, T.S.H. (2000) Factors influencing the adoption of Internet banking. Journal of the Association for Information Systems, 1, 1-42.

Then, N.K. \& DeLong, M.R. (1999) Apparel Shopping on the Web. Journal of Family and Consumer Sciences. 91(3), 65-68.

Venkatesh, V. (1999), "Creation of favorable user perceptions: exploring the role of intrinsic motivation", MIS Quarterly, Vol. 23 No.2, pp.239-60.

Venkatesh, V., Davis, F.D. (2000), "A theoretical extension of the technology acceptance model: four longitudinal field studies", Management Science, Vol. 46 No.2, pp.186-204.

Venkatesh, V., Morris, M.G. (2000), "Why don't men ever stop to ask for directions? Gender, social influence, and their role in technology acceptance and usage behavior", MIS Quarterly, Vol. 24 No.1, pp.115-39.

Yang, Z. \& Jun, M. (2002) Consumer Perception of E-service Quality: From Internet Purchaser and Non-purchaser Perspectives. Journal of Business Strategies, 19, 1, 19-41.

Zhang, P., and von Dran, G. M. (2001). User expectations and rankings of quality factors in different web site domains. International Journal of Electronic Commerce, 6(2), 9-33. 